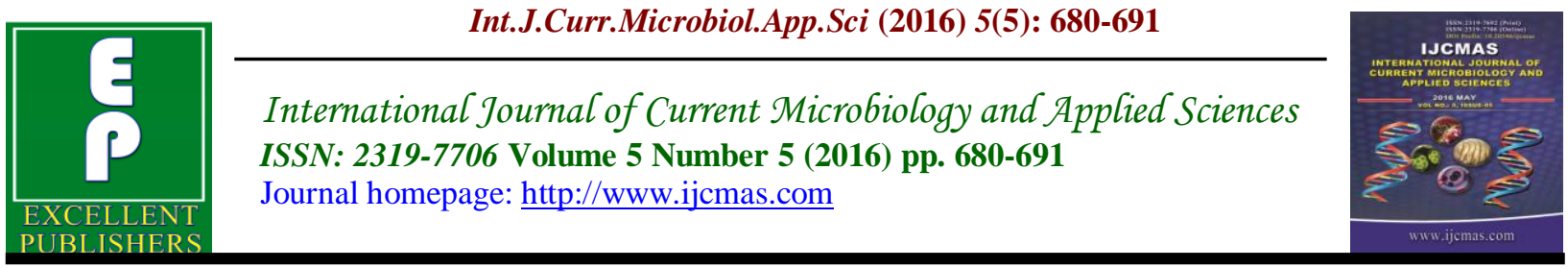

Original Research Article

http://dx.doi.org/10.20546/ijcmas.2016.505.069

\title{
Bioremediation of Oil Spill in Kingdom of Saudi Arabia by using Fungi Isolated from Polluted Soils
}

\author{
A.M. Moustafa* \\ Biology Department, College of Science and Arts, \\ Unaizah, Qassim University, KSA \\ *Corresponding author
}

\section{Keywords}

Bioremediation, oil spill, biodegradation, fungi, polluted soil, Saudi Arabia.

Article Info

Accepted:

18 April 2016

Available Online:

10 May 2016

\section{A B S T R A C T}

In the present study, soil samples were collected from Shaybah field (Ar Rub' al Khali), Aramco company (Dammam), Salwa beach and Dammam ports of Saudia Arabia. Soil fungi were isolated, identified and screened the ability of isolated fungi for crude oil biodegradation. Aspergillus niger and Fusarium oxysporum showed the highest frequency represented by $(9.8 \%)$ for each, followed by Drechslera spicifera, P.chrysogenum, which represented by $7.8 \%$ and $7.5 \%$ respectively. Penicillium documbens and Aspergillus flavus were represented by $7.2 \%$ for each, followed by Aspergillus candidus and Verticillium dahliae represented by $6.2 \%, 6.5 \%$ respectively. The biodegradability of isolated fungi was measured and the results showed that Aspergillus niger and Lichtheimia ramosa were the most efficient fungi in reducing of oil spill from the environment.

\section{Introduction}

Kingdom of Saudi Arabia is one of the world's largest producers of crude oil. Oil spills consider as an environmental pollutant which conducts by oil tankers or oil pipelines and leads to decline of human health due to carcinogenic impact of crude oil on human health during consumption of polluted water with oil spill. Oil spillage is the accidental discharge or pouring of crude oil into the environment, it involves the contamination of any part of the environment with any liquid hydrocarbon. These spills endanger public health, imperil drinking water, devastate natural resources, and disrupt the economy, Obire O.A. EC
(2009). Tons of hydrocarbons enter the environment through oil spill, tank leakages or wastewater disposal. These pollutants are toxic and hazardous to life. Their release into the environment has led to many environmental problems that are of global concern, Adekunle and Adebambo (2007). Nevertheless, some of the soil microorganisms that participated in soil processes such as transformation of nutrients are active hydrocarbon degraders (Ijah and Ukpe, 1992).

Oil spills consider one of the critical problems faces global nature due to impact of discharge pollutants which cause decline 
of environment health. Currently the nature became more familiar with biological control solutions to remove hazardous from the environment. Although disposal methods can become prohibitively expensive when the amounts of pollutants are huge, using microbial remediation process is successful and safe way to enhance environment health in particular with low cost, technique and high public acceptance to cleaning up soils from oil spills.

Bioremediation is the ability of microorganisms to degrade or detoxify organic contaminated area by transforming undesirable and harmful substances into non-toxic compound (Flowers et al., 1984).

Efforts to achieve biodegradation of oil products have involved bacteria and fungi, since they are the only biological species with metabolic capability of utilizing petroleum carbon for cell synthesis. In recent times, an increasing number of microbiological researches have been dedicated to bioremediation of oilcontaminated sites using various microbial species especially those indigenous to the contaminated environments (Odu, 1972). Naturally, soil is the richest reservoir of microorganisms and a key component of ecosystems, whenever soil is polluted, the ecosystem is altered and agricultural activities are affected too (Adekunle and Adebambo, 2007).

Fungi have been found to be better degraders of petroleum than traditional bioremediation techniques including bacteria, and although hydrocarbon degraders may be expected to be readily isolated from a petroleum oil- associated environment, the same degree of expectation may be anticipated for microorganisms isolated from a totally unrelated environment (Batelle, C.D. (2000) and Ojo, O.A. (2005)). Bartha and Atlas, (1977) listed
14 genera of isolated fungi which had been demonstrated to contain members which utilize petroleum hydrocarbon. The evolution of the hydrocarbon mixture depends on the nature of the oil, microbial community, and environmental factors which impact microbial activities.

The aim of this work were isolation and identification of soil fungi from oil polluted samples, then applying a safe method as biodegradation of oil spill by those isolated fungi to control environmental pollution in Kingdom of Saudi Arabia by testing the ability of fungal species isolated from crude oil contaminated soils and screen their ability in crude oil bioremediation.

\section{Materials and Methods}

Survey on polluted locations with oil spill in Kingdom of Saudi Arabia:

Samples have been collected from Shaybah field (Ar Rub' al Khali) and Aramco company (Dammam) close to tankers and pipelines release crude oil to the soil particles. Also, other soil samples have been collected near to Salwa and Dammam ports.

\section{Sample Collection and Culture Methods}

\section{Soil Samples}

Soil samples were collected (400 g) from surface $(0-15 \mathrm{~cm}$ depth) soil contaminated with crude oil. Samples were collected by using sterile spatula and stored in ice box to avoid contamination. In the lab, stones and other unwanted soil debris were removed by using $2 \mathrm{~mm}$ sieve.

\section{Crude Oil}

A sterilized bottles were filled with crude oil comes from tankers through the pipelines of Aramco company (Dammam). The bottles 
kept in ice box and transferred to refrigerator in the laboratory. The crude oil was sterilized using Millipore syringe filter and kept in sterilized bottle, and then crude oil kept till using with Bushnell-Haas broth medium to screen the ability of isolated fungi for bioremediation of crude oil.

\section{Culture Methods}

Soil fungi were estimated by soil dilution plate count method.

\section{Preparation of Fungal Growth Media}

To prepare 1 liter of Czapek's agar medium (30 g Sucrose, $3 \mathrm{~g} \mathrm{NaNo}_{3}, 1 \mathrm{~g} \mathrm{~K}_{2} \mathrm{HPO}_{4}, 0.5$ $\mathrm{g} \mathrm{Kcl}, 0.01 \mathrm{~g} \mathrm{Mg} \mathrm{So}_{4}, 0.1 \mathrm{~g} \mathrm{FeCl}_{2}$, and $20 \mathrm{~g}$ Agar). These chemicals have been dissolved into $1000 \mathrm{~mL}$ of distilled water respectively. To prepare Malt extract agar (20g Malt extract, powdered, $1 \mathrm{~g}$ Peptone, $20 \mathrm{~g}$ Glucose and $20 \mathrm{~g}$ Agar) were dissolved into $1000 \mathrm{ml}$ of distilled water. Rose Bengal ( $2 \mathrm{ml} / \mathrm{L}$ ) was added to each medium to inhibit bacterial growth. Streptomycin (500mg /L) as antibiotic inhibit bacterial growth was added to each media after sterilization process by autoclave. $1 \mathrm{~mL}$ of each dilution transferred into petri dish using sterilized pipette, triplicates from each dilution have done.

\section{Identification of Fungal Isolates}

Soil fungi were estimated by soil dilution plate count method. Inoculate $1 \mathrm{ml}$ of each dilution in the bottom of the plate, pour the medium and shake carefully. Incubate for 7 days at $28^{\circ} \mathrm{C}$.

\section{Purification of Fungal Species}

After isolation and identification of fungi, fungal species have been purified separately on sterilized PDA plates. Potato Dextrose Agar (PDA) was prepared from (250 g of potatoes, $20 \mathrm{~g}$ glucose and $15 \mathrm{~g}$ agar) dissolved in $1000 \mathrm{ml}$ distilled water. The pure culture isolates were identified following the morphological characters and microscopic examinations according to taxonomy keys in the following literatures : Raper \& Fennel (1965);Smith,1969; Booth, 1971; Ellis, (1971 \& 1976); Arx, (1981); Barnett and Pankhurst,(1972); Alexopoulos, and Mims, (1979); O’Donnell, (1979); Campbell and Steward (1980); Domsch, et al. (1980); Goh and Clement (2003).

\section{Biodegradability Test - DCPIP Indicator}

According to Hanson et al., (1993), screening procedure to evaluate fungal ability for oil biodegradation. This method is simple and reliable technique for screening of crude oil degrading microorganisms. However, majority of other methods are either time consuming, laborious, expensive or not reliable enough. The principle of this technique is that during the microbial oxidation of the carbon source, electrons are transferred to electron acceptors such as $\mathrm{O} 2$, nitrates, and sulphates. By incorporating an electron acceptor such as DCPIP to the culture medium, it is possible to ascertain the ability of the microorganism to utilize the substrate by observing the color change of DCPIP from blue (oxidized) to colorless (reduced).

To measure weight loss of fungal strains, weight loss method of Bartha and Bossert (1984) was used in the present study. 10mls of crude oil broth was prepared in a test tube and inoculated with $0.1 \mathrm{ml}$ of filtrate from a soil sample. The test tube was then incubated at $35 \pm 2^{\circ} \mathrm{C}$ being shaken on a mechanical shaker for 10 minutes at 200 rpm. After 48 hours, the remaining crude oil was separated using a separator funnel, and weighed. The percentage degradation of the crude oil was then calculated as described by Ijah and Ukpe (1992). 
Weight of crude oil (initial) - Weight of crude oil (after treatment) x 100

Weight of crude oil (initial)

This technique has been employed in other works including: Cormack and Fraile (1997), Roy et al., (2002), Pirôllo et al., (2008), Mariano et al., (2009), and Junior et al., (2009).

\section{Results and Discussion}

The results from table (1) showed that Aspergillus niger and Fusarium oxysporum were the highest frequency represented by $(9.8 \%)$ for each, followed by Drechslera spicifera, P.chrysogenum, which represented by $7.8 \%$ and $7.5 \%$ respectively.

Penicillium documbens and Aspergillus flavus were represented by $7.2 \%$ for each, followed by Aspergillus candidus, and Verticillium dahliae represented by $6.2 \%$, $6.5 \%$ respectively.

While Lichtheimia ramosa and Rhizopus stolonifer were represented by $2.3 \%$ for each which show the lowest frequency of occurrence.

Seventeen fungal isolates recovered from oil-contaminated soils were screened for crude oil biodegradation activity in a shakeflask culture. Among the seventeen fungal isolates, only seven showed potentials for biodegradation. Of these seven isolates, two of them identified as Aspergillus niger and Lichtheimia ramosa which showed the highest ability of crude oil biodegradation.

The screening method used in the present study depends on changing in the color of fungal isolates treated with redox indicator technique, so the fungal isolates which has the ability to degrade crude oil in the presence of redox indicator, confirmed the ability of four fungi: Aspergillus niger, Penicillium documbens, Lichtheimia ramosa and Fusarium oxysporum to biodegrade crude oil. A moderate ability was observed by Fusarium solani, Penicillium chrysogenum and Aspergillus flavus. Although Aspergillus and Penicillium species were recorded in former studies as crude oil biodegraders, the present study confirmed that the fungus Lichtheimia ramosa demonstrated as a new record fungus which has biodegradation ability. An interesting finding from this work is that Lichtheimia ramosa had not previously been reported as oil degrader.

Biodegradation is increasingly being considered as a less expensive alternative to physical, mechanical and chemical means of disposing hydrocarbon pollutants. The ubiquitous distribution of fungi and their ready isolation from oil-contaminated environments indicate that they play an important role in the degradation of oil spilled in the environment. Fungi have evolved the ability to degrade petroleum hydrocarbons, and, unlike other groups of microorganisms, filamentous fungi do not exhibit preferential degradation for particular chain lengths of alkanes. Fungal mycelia penetrate oil and increase the surface area available for degradation than other microbes. Fungi are notably aerobic and can also grow under environmentally stressed conditions such as low $\mathrm{pH}$ and poor nutrient status, where bacterial growth might be limited. Finally, fungi are easy to transport, genetically engineer, and produce in large quantities. 
Int.J.Curr.Microbiol.App.Sci (2016) 5(5): 680-691

Table.1 Frequency of Occurrence of Isolated and Identified Fungi

\begin{tabular}{|c|c|c|c|c|c|c|}
\hline Fungi & Alternaria & Stachybotrys sp. & \multicolumn{2}{|c|}{ Penicillium spp. } & Lichtheimia & Rhizopus \\
\hline Soil samples & $\begin{array}{c}\text { Alt. } \\
\text { alternata }\end{array}$ & S. cylindrospora & P.documbens & P.chrysogenum & L. ramose & $\begin{array}{c}R . \\
\text { stolonifer }\end{array}$ \\
\hline Soil 1 & 0 & 1 & 0 & 1 & 0 & 1 \\
\hline Soil 2 & 2 & 0 & 1 & 2 & 0 & 1 \\
\hline Soil 3 & 0 & 1 & 2 & 0 & 1 & 0 \\
\hline Soil 4 & 1 & 0 & 3 & 1 & 0 & 0 \\
\hline Soil 5 & 1 & 2 & 0 & 0 & 1 & 0 \\
\hline Soil 6 & 1 & 1 & 0 & 2 & 1 & 0 \\
\hline Soil 7 & 2 & 0 & 0 & 3 & 0 & 0 \\
\hline Soil 8 & 1 & 3 & 1 & 4 & 0 & 0 \\
\hline Soil 9 & 2 & 1 & 2 & 0 & 0 & 0 \\
\hline Soil 10 & 3 & 0 & 0 & 0 & 0 & 0 \\
\hline Soil 11 & 2 & 0 & 0 & 0 & 1 & 0 \\
\hline Soil 12 & 0 & 0 & 2 & 2 & 0 & 0 \\
\hline Soil 13 & 0 & 1 & 0 & 1 & 0 & 1 \\
\hline Soil 14 & 0 & 0 & 1 & 3 & 0 & 1 \\
\hline Soil 15 & 0 & 1 & 2 & 0 & 0 & 0 \\
\hline Soil 16 & 2 & 0 & 3 & 0 & 1 & 0 \\
\hline Soil 17 & 1 & 0 & 0 & 1 & 0 & 0 \\
\hline Soil 18 & 1 & 0 & 1 & 2 & 1 & 0 \\
\hline Soil 19 & 0 & 1 & 2 & 0 & 0 & 0 \\
\hline Soil 20 & 0 & 2 & 0 & 0 & 0 & 2 \\
\hline Soil 21 & 0 & 0 & 2 & 1 & 1 & 1 \\
\hline Total count & 19 & 14 & 22 & 23 & 7 & 7 \\
\hline $\begin{array}{l}\text { Frequency of } \\
\text { occurrence }\end{array}$ & 6.2 & 4.6 & 7.2 & 7.5 & 2.3 & 2.3 \\
\hline
\end{tabular}


Table.1 Continued...

Frequency of Occurrence of Isolated and Identified Fungi

\begin{tabular}{|c|c|c|c|c|c|}
\hline Fungi & \multicolumn{2}{|c|}{ Fusarium spp. } & $\begin{array}{c}\text { Stemphylium } \\
\text { sp. }\end{array}$ & $\begin{array}{c}\text { Cunnighamella } \\
\text { sp. }\end{array}$ & $\begin{array}{c}\text { Drechslera } \\
\text { sp. }\end{array}$ \\
\hline Soil samples & F. solani & F. oxysporum & S. botryosum & C. elegans & D. spicifera \\
\hline Soil 1 & 0 & 0 & 2 & 1 & 1 \\
\hline Soil 2 & 0 & 2 & 3 & 1 & 0 \\
\hline Soil 3 & 0 & 3 & 1 & 0 & 2 \\
\hline Soil 4 & 1 & 5 & 0 & 1 & 3 \\
\hline Soil 5 & 1 & 0 & 2 & 0 & 0 \\
\hline Soil 6 & 0 & 3 & 1 & 1 & 0 \\
\hline Soil 7 & 1 & 0 & 0 & 0 & 1 \\
\hline Soil 8 & 1 & 1 & 2 & 0 & 2 \\
\hline Soil 9 & 1 & 0 & 1 & 0 & 1 \\
\hline Soil 10 & 1 & 0 & 3 & 1 & 0 \\
\hline Soil 11 & 0 & 1 & 2 & 1 & 0 \\
\hline Soil 12 & 1 & 2 & 0 & 1 & 3 \\
\hline Soil 13 & 0 & 3 & 0 & 0 & 2 \\
\hline Soil 14 & 0 & 5 & 1 & 1 & 0 \\
\hline Soil 15 & 1 & 0 & 2 & 2 & 1 \\
\hline Soil 16 & 0 & 0 & 0 & 0 & 4 \\
\hline Soil 17 & 1 & 0 & 0 & 1 & 2 \\
\hline Soil 18 & 2 & 2 & 0 & 0 & 2 \\
\hline Soil 19 & 1 & 2 & 0 & 1 & 0 \\
\hline Soil 20 & 2 & 1 & 0 & 0 & 0 \\
\hline Soil 21 & 0 & 0 & 0 & 1 & 0 \\
\hline Total count & 14 & 30 & 20 & 13 & 24 \\
\hline $\begin{array}{l}\text { Frequency of } \\
\text { occurrence }\end{array}$ & 4.6 & 9.8 & 6.5 & 4.2 & 7.8 \\
\hline
\end{tabular}


Table.2 Biodegradability Experiment (Change from Blue to Colorless)

\begin{tabular}{|c|c|c|c|}
\hline Fungal species & $\begin{array}{c}\text { Decolourization after } \\
7 \text { days }\end{array}$ & $\begin{array}{c}\text { Decolourization after } 14 \\
\text { days }\end{array}$ & $\begin{array}{c}\text { Decolourization after } 21 \\
\text { days }\end{array}$ \\
\hline Aspergillus sydowii & - & - & - \\
\hline Aspergillus niger & ++ & +++ & +++ \\
\hline Aspergillus flavus & - & + & + \\
\hline Aspergillus candidus & - & - & - \\
\hline Verticillium alfalfae & - & - & - \\
\hline Verticillium dahliae & - & - & - \\
\hline Rhizopus stolonifer & - & - & - \\
\hline Lichtheimia ramosa & + & ++ & +++ \\
\hline Penicillium chrysogenum & - & + & + \\
\hline Penicillium documbens & ++ & +++ & +++ \\
\hline Stachybotrys cylindrospora & - & - & - \\
\hline Alternaria alternata & - & - & - \\
\hline Drecshlera spicifera & - & - & - \\
\hline Cunninghamella elegans & - & - & - \\
\hline Stemphvlium botrvosum & - & - & - \\
\hline Fusarium oxysporum & + & + & ++ \\
\hline Fusarium solani & + & + & ++ \\
\hline
\end{tabular}

$-=$ no change in colour $\quad+=$ negligible change $\quad++$ moderate change $\quad+++=$ colorless

Table.3 Percent Weight Loss of Crude Oil Degraded by Isolates, after Inoculation (Days)

\begin{tabular}{|c|c|c|c|c|c|c|}
\hline \multirow[t]{3}{*}{ Fungal species } & \multicolumn{6}{|c|}{ Percent weight loss after inoculation } \\
\hline & \multicolumn{2}{|c|}{7 days } & \multicolumn{2}{|c|}{14 days } & \multicolumn{2}{|c|}{21 days } \\
\hline & 1 & $2 *$ & 1 & $2 *$ & 1 & $2 *$ \\
\hline Aspergillus candidus & 0 & 0 & 0 & 0 & 0 & 0 \\
\hline Aspergillus flavus & 0 & 0 & 0 & 0 & 0 & 0 \\
\hline Aspergillus sydowii & 0 & 0 & 0 & 0 & 0 & 0 \\
\hline Aspergillus niger & $3.2 \pm 0.3$ & $3 \pm 0.3$ & $6.1 \pm 0.8$ & $6 \pm 0.8$ & $7.8 \pm 0.6$ & $7.7 \pm 0.6$ \\
\hline Cunnighamella elegans & 0 & 0 & 0 & 0 & 0 & 0 \\
\hline Drechslera spicifera & 0 & 0 & 0 & 0 & 0 & 0 \\
\hline Fusarium solani & 0 & 0 & 0 & 0 & 0 & 0 \\
\hline Fusarium oxysporum & $0.7 \pm 0.3$ & $0.7 \pm 0.3$ & $1.9 \pm 0.6$ & $1.9 \pm 0.6$ & $1.9 \pm 0.5$ & $1.9 \pm 0.5$ \\
\hline Penicillium chrysogenum & 0 & 0 & 0 & 0 & 0 & 0 \\
\hline Penicillium documbens & $1.5 \pm 1.0$ & $1.5 \pm 1.0$ & $2.1 \pm 0.6$ & $2.2 \pm 0.6$ & $3.3 \pm 0.5$ & $3.4 \pm 0.5$ \\
\hline Rhizopus stolonifer & 0 & 0 & 0 & 0 & 0 & 0 \\
\hline Verticillium dahliae & 0 & 0 & 0 & 0 & 0 & 0 \\
\hline Verticillium alfalfa & 0 & 0 & 0 & 0 & 0 & 0 \\
\hline Alternaria alternata & 0 & 0 & 0 & 0 & 0 & 0 \\
\hline Lichtheimia ramosa & $2.5 \pm 0.4$ & $2.5 \pm 0.4$ & $4.9 \pm 0.7$ & $4.9 \pm 0.7$ & $8.7 \pm 0.3$ & $8.6 \pm 0.3$ \\
\hline Stemphylium botryosum & 0 & 0 & 0 & 0 & 0 & 0 \\
\hline Stachybotrys cylindrospora & 0 & 0 & 0 & 0 & 0 & 0 \\
\hline
\end{tabular}


Table.4 Statistical Analysis of Percent Weight Loss of Crude Oil after Incubation Periods (Means \& Sd)

\begin{tabular}{|c|c|c|c|c|c|c|c|c|c|c|c|c|}
\hline \multirow{4}{*}{ Fungi } & \multicolumn{9}{|c|}{ Incubation period (days) } & \multirow{2}{*}{\multicolumn{3}{|c|}{ Overall }} \\
\hline & \multicolumn{3}{|c|}{7} & \multicolumn{3}{|c|}{14} & \multicolumn{3}{|c|}{21} & & & \\
\hline & \multicolumn{2}{|c|}{ Means } & \multirow[t]{2}{*}{ SD } & \multicolumn{2}{|c|}{ Means } & \multirow[t]{2}{*}{ SD } & \multicolumn{2}{|c|}{ Means } & \multirow[t]{2}{*}{ SD } & \multicolumn{2}{|c|}{ Means } & \multirow[t]{2}{*}{$\mathrm{SD}$} \\
\hline & Abs & Trans & & Abs & Trans & & Abs & Trans & & Abs & Trans & \\
\hline Aspergillus niger & 3.10 & 1.76 & 0.04 & 6.05 & 2.46 & 0.01 & 7.75 & 2.78 & 0.01 & $5.63^{\mathrm{A}}$ & 2.33 & 0.47 \\
\hline Fusarium oxysporum & 0.70 & 0.84 & 0.00 & 1.90 & 1.38 & 0.00 & 1.90 & 1.38 & 0.00 & $1.50^{\mathrm{D}}$ & 1.20 & 0.28 \\
\hline Lichtheimia ramosa & 2.50 & 1.58 & 0.00 & 4.90 & 2.21 & 0.00 & 8.65 & 2.94 & 0.01 & $5.35^{\mathrm{B}}$ & 2.24 & 0.61 \\
\hline Penicillium documbens & 1.50 & 1.22 & 0.00 & 2.15 & 1.47 & 0.02 & 3.35 & 1.83 & 0.01 & $2.33^{\mathrm{C}}$ & 1.51 & 0.27 \\
\hline Overall & $1.95^{\mathrm{c}}$ & 1.35 & 0.38 & $3.75^{\mathrm{b}}$ & 1.88 & 0.50 & $5.41^{\mathrm{a}}$ & 2.23 & 0.69 & & & \\
\hline \multicolumn{13}{|c|}{ ANOVA } \\
\hline SOV & \multicolumn{3}{|c|}{ Df } & \multicolumn{6}{|c|}{ MS } & \multicolumn{3}{|c|}{ Sig. } \\
\hline Fungi (F) & \multirow{2}{*}{\multicolumn{3}{|c|}{$\begin{array}{l}3 \\
2\end{array}$}} & \multicolumn{6}{|c|}{1.853} & \multicolumn{3}{|c|}{$0.000 * * * *$} \\
\hline Incubation (I) & \multirow{2}{*}{\multicolumn{3}{|c|}{$\frac{2}{6}$}} & \multicolumn{6}{|c|}{1.578} & \multicolumn{3}{|c|}{$0.000 * * * *$} \\
\hline $\mathrm{F} * \mathrm{I}$ & & & & \multirow{2}{*}{\multicolumn{6}{|c|}{$\begin{array}{c}0.092 \\
0.00025\end{array}$}} & \multirow{2}{*}{\multicolumn{3}{|c|}{$0.000 * * * *$}} \\
\hline Error & \multicolumn{3}{|c|}{12} & & & & & & & & & \\
\hline
\end{tabular}

Fig.1 Biodegradation Ability of Crude Oil by Fungal Species (from the left - control and Aspergillus niger ).

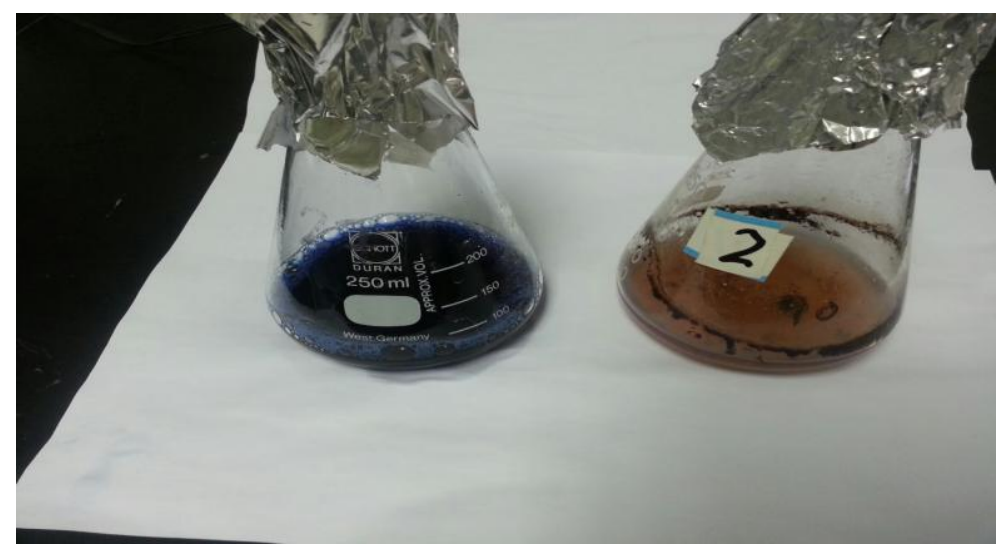

Fig.2 Biodegradation Ability of Crude Oil by other Fungal Species :figure (2) (moderate change in color)

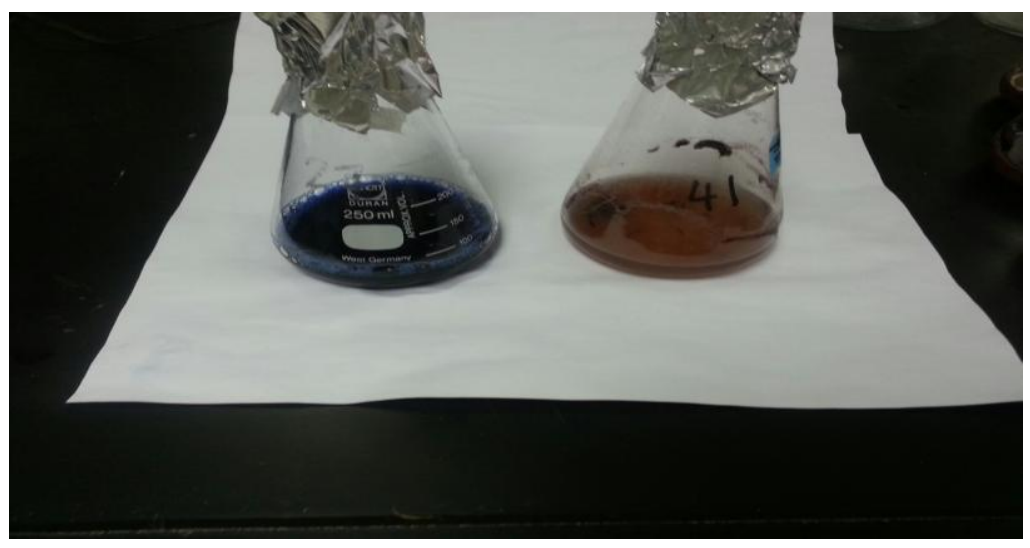


Fig.3 Biodegradation Ability of Crude oil by Fungal Species (From the left - Control and Lichtheimia ramosa).

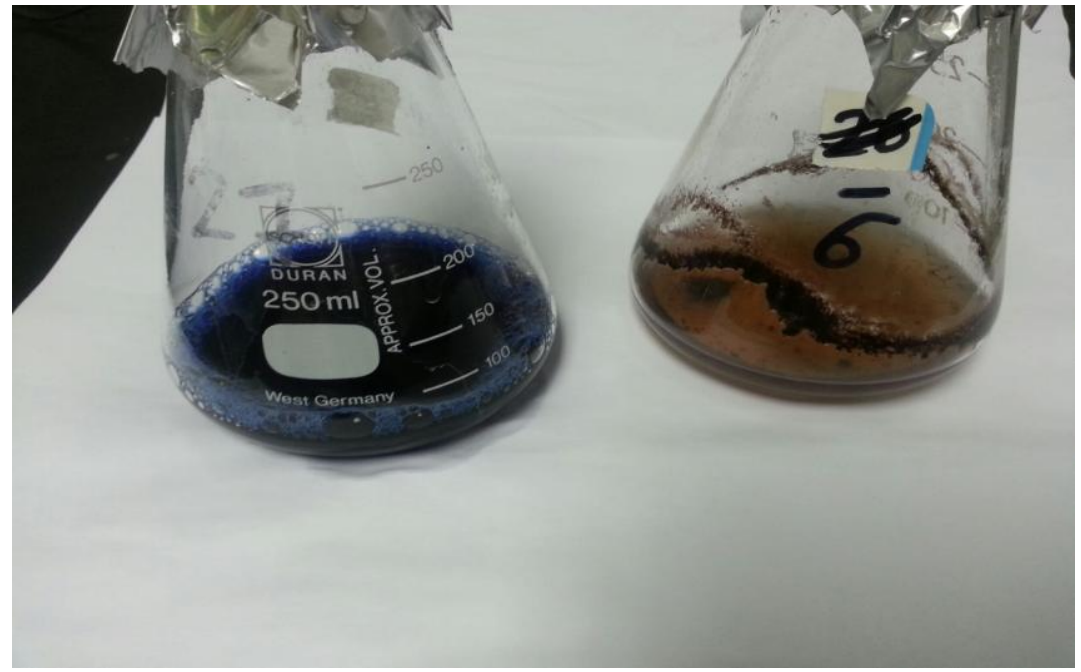

Fig.4 Fungi Represent the Highest Ability to Degrade Crude oil

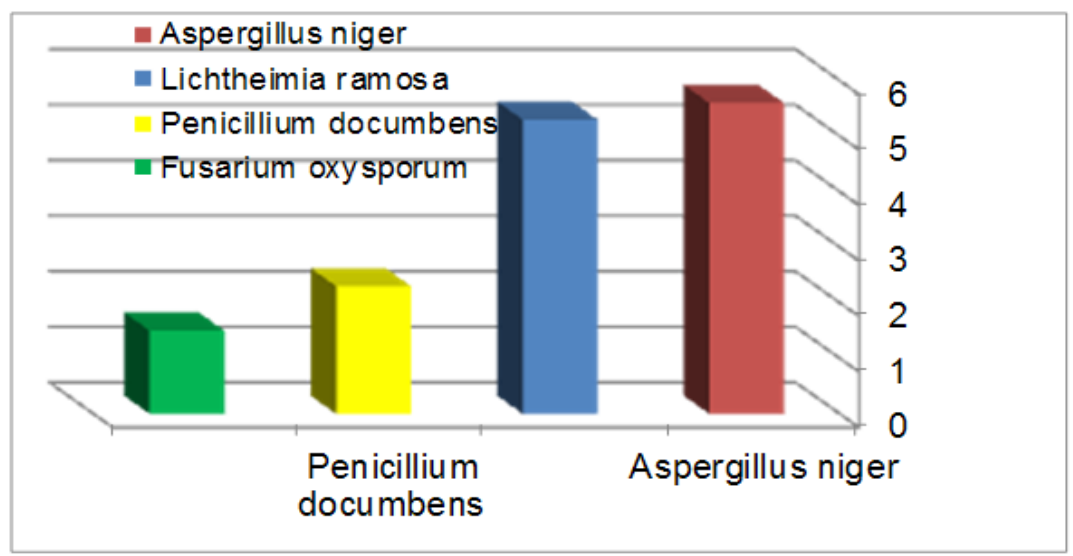

In the present work Aspergillus niger, Penicillium documbens, Lichtheimia ramosa and Fusarium oxysporum were the perfect fungal isolates demonstrated active ability to biodegrade crude oil, this result agree with results of Gesinde et al., (2008) who indicated that Aspergillus niger have very active degradation capabilities of four kinds of oil compounds, Durb oil, Escravos light, Arabian light and Bonny light. Furthermore, in comparison with eight other genera, Aspergillus, Penicillium and Fusarium species were the most efficient metabolizers of hydrocarbons (Obire et al., (2008); De et al., (2000).
In the present work Aspergillus niger, Penicillium documbens, Lichtheimia ramosa and Fusarium oxysporum were the perfect fungal isolates were confirmed for biodegradation ability of crude oil. Aspergillus niger recorded the highest weight loss $(5.6 \%)$, followed by the isolated fungi belongs to Aspergillus niger with higher activity followed by Lichtheimia ramosa and Penicillium documbens which were able to degrade $5.4 \%$ and $2.3 \%$ of crude oil, this results are closely similar to Al-Nasrawi, (2012) who had reported that five species confirmed for biodegradation ability of crude oil, Cochliobolus lutanus 
and Fusarium solani. Aspergillus niger recorded the highest weight loss of $8.6 \%$, (7.9\%) and Cochliobolus lutanus (4.7\%) strain $421502 \quad$ (1.9\%).Also, several researchers studied the role of fungi in biodegradation process of petroleum products and the most common fungi which have been recorded as a biodegrades belongs to following genera: Alternaria, Aspergillus, Candida, Cephalosporium, Cladosporium, Fusarium, Geotrichum, Gliocladium, Mucor, Paecilomyces, Penicillium, Pleurotus, Polyporus, Rhizopus, Rhodotolura, Saccharomyces, Talaromyces and Torulopsis. (Adekunle and Adebamo, 2007; Hadibarata and Tachibana, 2009a; Hadibarata, and Tachibana, 2009b; Adekunle, et al., 2004; Gesinde, et al., 2008; Atagana et al., 2006; Husaini, et al., 2009; Obire and Anyanwu, 2009; Cristina Romero, et al., 2009; Saraswathy and Hallberg, 2002 ).

It is recommended that the crude oil which cannot be recovered after a spill should therefore be subjected to bioremediation using fungi and fungal products such as their enzymes may benefit from development of indigenous fungi for bioremediation. In the field, it is recommended that the crude oil which cannot be recovered after a spill should be subjected to bioremediation using fungi and fungal products such as their enzymes may beneficial for bioremediation.

\section{Acknowledgement}

I would like to thank Deanship Of Scientific Research at Qassim University for financial support.

\section{References}

Adekunle, A.A., Adebambo, O.A. 2007. Petroleum Hydrocarbon Utilization by Fungi Isolated From Detarium
Senegalense (J. F Gmelin) Seeds, $J$. American Sci., 3(1): 69-76.

Adekunle, A.A., Uaboni-Egbenni, P.O., Ajayi, T. 2004. Biodegradation of petroleum products by Saccharomyces cerevisae isolated from the Lagos lagoon. 17: 83- 94.

Aerobic biodegradation of butanol and gasoline blends. Biom. Bioenergy, 33: 1175-1181.

Alexopoulos, C.J., Mims, C.W. 1979. Introductory Mycology.3rd Ed.632 p.

Al-Nasrawi, Hussein. 2012. Biodegradation of Crude Oil by Fungi Isolated from Gulf of Mexico. J. Bioremed. Biodegrad, volume 3, Issue 4.1000147.

Arx, J.A.V. 1981. The genera of fungi sporulating in pure culture. Strauss and Cramer Gmbh, Germany 424 pp.

Atagana, H.I., R.J. Haynes, Wallis, F.W. 2006. Fungal bioremediation of creosote-contaminated soil : A laboratory scale bioremediation study using indigenous soil fungi. Water Air Soil Pollut., 172: 201-219.

Bartha, R., Atlas, R.M. 1977. The microbiology of aquatic oil spills. Adv. Appl. Microbiol., 22: 225-266.

Bartha, R., Bossert, I. 1984. The fate of petroleum in soil ecosystems. In: Petroleum.

Batelle, C.D. 2000. Mushrooms: Higher Macrofungi to clean up the environment. Environmental Issues, Fall 2000.

Bernett, H.L., Hunter, B.B. 1972. Illustrated Genera of Imperfect Fungi. 3rd Edition.Burgess Publishing Company, U.S.A.

Booth, C. 1971. The genus Fusarium. Commonwealth Mycological Institute, Kew, Surrey, England.

Campbell, M.C., Stewart, J.L. 1980. Identification of individual fungal isolates. In: Tommaso, E., Zirken, M. 
(Eds.), The Medical Mycology Handbook. John Wiley \& Sons, New York, USA, pp.210-343.

Cormack, W.P.M., Fraile, E.R. 1997. Characterization of a hydrocarbon degrading psychrotrophic Antarctic bacterium. Antarctic Sci., 9(2): 150155.

Cristina Romero, 1., M.M., Inés Urrutia, H., Enso Reinoso1, Moreno Kiernan. M. 2010. Benzo [a] pyrene degradation by soil filamentous fungi, J. Yeast and Fungal Res., 1(2): 025-029.

De, N., Bello, Y.M., Saleh, M. 2000. Biodegradation of crude oil by Fusarium sp. and Trichoderma sp. Isolated from oil contaminated soil in different auto mechanic garages.

Domsch, K.H., Gams, W., Anderson, T.H. 1980. Compendium of soil fungi. 2 vos. London, Academic Press. 859 pp.

Ellis, M.B. 1971. Dematiaceous Hyphomycetes. Common wealth Mycological Institute. Kew, Surrey, England. pp.608.

Ellis, M.B. 1976. More dematiaceous Hyphomycetes. Common wealth Mycological Institute. Kew, Surrey, England. pp.507.

Flowers, T.H., Pulford, I.D., Duncan, H. J. 1984. Studies on the breakdown of oil in soil. Environ. Poll., (Series B.) 8: 71-82 from oil spilled soil. Waste Manag., 12: 55-60.

Gesinde, A.F., E.B., Agbo, M.O., Agho, E.F.C., Dike. 2008. Bioremediation of Some Nigerian and Arabian Crude Oils by Fungal Isolates, Int. Jor. P. App. Scs., 2(3): 37-44.

Goh, T.K., Clement, K.M.T. 2003. Key to common dematiaceous hyphomycetes from freshwater. Fungal diversity Research series, 10: 325-343.

Hadibarata, T., Tachibana, S. 2009a. Microbial Degradation of n-Eicosane by Filamentous Fungi,

Interdisciplinary Studies on Environmental ChemistryEnvironmental Research in Asia, Eds., Y. Obayashi, T. Isobe, A. Subramanian, S. Suzuki and S. Tanabe, pp. 323-329.

Hadibarata, T., Tachibana, S. 2009b. Microbial Degradation of Crude Oil by Fungi Pre-Grown on Wood Meal, Interdisciplinary Studies on Environmental Chemistry, Environmental Research in Asia, Eds., Y. Obayashi, T. Isobe, A. Subramanian, S. Suzuki and S. Tanabe, pp. 317-322.

Hanson, K.G., Desai, J.D., Desai, A.J. 1993. A rapid and simple screening technique for potential crude oil degrading microorganisms.

Biotechnol. Tech., 7: 745-748.

Husaini, A., H.A., Roslan, K.S.Y., Hii, C.H. Ang. 2008. Biodegradation of aliphatic hydrocarbon by indigenous fungi isolated from used motor oil contaminated sites. World J. Microbiol. Biotechnol., 24(12): 27892797.

Ijah, U.J.J., Ukpe, L.I. 1992. Biodegradation of crude oil by Bacillus strains 28A and 61B isolated JohnWiley \& Sons Inc., New York.

Junior, J.S., Mariano, A.P., Angelis, D.F. 2009. Biodegradation of biodiesel/diesel blends by Candida viswanathii. Afr. J. Biotechnol., 8(12): 2774-2778.

Mariano, A.P., Tomasella, R.C., Di Martino, C., Maciel Filho, R., Seleghim, M.H.R., Contiero, J., Angelis, D.F. 2009. Microbiology (Atlas, R.M.,ed.). Macmillan Publishing Company. New York. Pp 579-580.

Obire, O., Anyanwu, E.C. 2009. Impact of various concentrations of crude oil on 
fungal populations of soil. Int. J. Environ. Sci. Technol., 6: 211-218.

Obire, O., E.C. Anyanwu, Okigbo, R.N. 2008. Saprophytic and crude oildegrading fungi from cow dung and poultry droppings as bioremediating agents. Int. J. Agri. Technol., 4(2): 8189.

Obire, O., E.C. Anyanwu. 2009. Impact of various concentrations of crude oil on fungal populations of soil. Int. J. Environ. Sci. Tech., 6(2): 211-218.

Odu, C.T.I. 1972. Microbiology of soils contaminated with petroleum hydrocarbons. Extent of contamination and some soil and microbial properties after contamination. J. Institute of Petroleum, 58(562): 201-208.

Ojo, O.A. 2005. Petroleum - hydrocarbon utilization by nature bacterial population from a Wastewater canal Southwest Nigeria. African $J$. Biotechnol., 5(4): 333 - 337.
Pirollo, M.P.S., Mariano, A.P, Lovaglio, R.B., Costa, S.G.V.A.O., Walter, V., Hausmann, R., Contiero, J. 2008. Biosurfactant synthesis by Pseudomonas aeruginosa LBI isolated from a Hydrocarbon contaminated site. J. Appl. Microbiol., 105: 14841490.

Raper, K.B., Fennel, D.J. 1965. The Genus Aspergillus. Williams and Wilkins, Baltimore, $686 \mathrm{pp}$.

Roy, S., Hens, D., Biswas, D., Kumar, R. 2002. Survey of petroleumdegrading bacteria in coastal waters of Sunderban Biosphere Reserve. World J. Microbiol. Biotechnol., 18: 575581.

Saraswathy, A., Hallberg, R. 2002. Degradation of pyrene by indigenous fungi from a former gasworks site. FEMS Microbiol. Lett., 210(2): 227-32.

\section{How to cite this article:}

Moustafa, A.M., 2016. Bioremediation of Oil Spill in Kingdom of Saudi Arabia by using Fungi Isolated from Polluted Soils. Int.J.Curr.Microbiol.App.Sci.5(5: 680-691. doi: http://dx.doi.org/10.20546/ijcmas.2016.505.069 